\title{
Bacterial Strain BA-3 and a filterable factor cause a white plague-like disease in corals from the Eilat coral reef
}

\author{
Y. Barash ${ }^{1}$, R. Sulam² ${ }^{2}$ Y. Loya ${ }^{2}$, E. Rosenberg ${ }^{1, *}$ \\ ${ }^{1}$ Department of Molecular Microbiology and Biotechnology, and ${ }^{2}$ Department of Zoology, George S. Wise Faculty of Life Sciences, \\ Tel Aviv University, Ramat Aviv 69978, Israel
}

\begin{abstract}
During the last 2 years a white plague-like disease has spread over the Eilat coral reef, Gulf of Aqaba, Red Sea. Two of the major reef-building coral genera, Favia and Goniastrea, were most affected by this disease. Approximately $10 \%$ of these corals showed progressive signs of the disease or were already dead as a result of the disease. Controlled aquarium experiments demonstrated that the disease is infectious and that transmission from diseased to healthy corals does not require direct contact. Infection was not genus-specific, since diseased F. favus infected 3 other coral genera. Although diseased F. favus contained 80 to 10000 times more culturable bacteria than healthy specimens, none of the 25 isolates initially tested infected healthy corals. Filtration of aquarium water containing diseased F. favus indicated that the infectious agent was larger than $0.2 \mu \mathrm{m}$ and smaller than $3 \mu \mathrm{m}$. Microorganisms retained by the $0.2 \mu \mathrm{m}$ filter did not infect corals; however, when the retentate was combined with the $0.2 \mu \mathrm{m}$ filtrate, infection took place. This suggested that the infectious agent requires a filterable factor to cause the disease. Combining the $0.2 \mu \mathrm{m}$-filtered water from an aquarium containing a diseased coral with each of the 25 pure cultures previously obtained from diseased $F$. favus allowed for the recognition of 1 strain that caused rapid lysis of $F$. favus. The pathogen, referred to as BA-3, is a Gram-negative bacterium whose 16S rDNA sequence indicates it is a new species and possibly a new genus. Attempts to re-isolate Strain BA-3 from diseased corals in the field were unsuccessful. The nature of the filterable factor, which is $>5000$ molecular weight (MW) and heat sensitive, remains to be determined.
\end{abstract}

KEY WORDS: Coral disease $\cdot$ Coral white plague $\cdot$ Favia favus $\cdot$ Eilat coral reef

\section{INTRODUCTION}

Infectious disease in scleractinian corals is one of the primary causes of the current global deterioration of coral reef ecosystems (Green \& Bruckner 2000, Loya et al. 2001, Rosenberg \& Loya 2004). Of the more than 30 coral diseases that have been described (Weil 2004), relatively few have been studied systematically. To date, the microorganism responsible for a specific coral disease has been isolated and characterized in only 5 cases: Aurantimonas coralicida for white plague Type II (Denner et al. 2003), Aspergillus sydowii for sea fan disease (Geiser et al. 1998), Serratia marcescens for white pox disease (Patterson et al. 2002), Vibrio shiloi for bleaching Oculina patagonia (Kushmaro et al. 1996, 1997) and $V$. coralliilyticus for bleaching and lysis of Pocillopora damicornis (Ben-Haim \& Rosenberg 2002, Ben Haim et al. 2003a,b). Isolation of the causative agent is a key step in understanding a disease and developing methods of controlling it.

Until recently, the Eilat coral reef, situated on the most northern boundaries of the distribution of coral reefs, has been relatively free of signs of disease typical of the Caribbean, such as black band disease, white pox, white plague and other 'white' diseases. However, during the last 4 years (2000 to 2004) many of these diseases have appeared in the northern Gulf of Aqaba (Loya 2004). At present, little is known about 
the ecology and pathology of coral diseases in Red Sea reefs in general (Antonius \& Riegl 1997) and Eilat's reefs in particular. The most important current disease on the Eilat reef quantitatively and from the point of view of mortality is one that affects a variety of massive and encrusting corals that shows signs of the white plague disease: a sharp boundary between apparently healthy tissue and freshly exposed skeleton, with no build-up of microorganisms or necrotic tissue visible to the naked eye (Bythell et al. 2004). White plague was first reported by Dustan (1977). Since that time other outbreaks of white plague have occurred in the Caribbean, but with faster rates of progression (Richardson 1998). Dustan's (1977) original proposal that 'plague appears to be a suite of diseases that result in the death of coral tissue ...' appears to be correct. The causative agent of White Plague II has been reported. Originally classified as a Sphingomonas sp. (Richardson et al. 1998), the Gram-negative bacterium was subsequently studied in more detail and published as a novel genus (Aurantimonas coralicida gen. nov. sp. nov.; Denner et al. 2003).

The aim of the present study was to test if the white plague-like disease on the Eilat coral reef was an infectious disease and, if so, to isolate the causative agent. The most interesting finding was that a pure culture of a bacterium isolated from a diseased coral caused the rapid lysis of corals in aquarium experiments when it was supplemented with a filterable factor present in the seawater surrounding a diseased coral.

\section{MATERIALS AND METHODS}

Collection and maintenance of corals. Healthy corals (no signs of disease) were collected by SCUBA diving off Eilat in the Gulf of Aqaba, Red Sea, at depths of 4 to $7 \mathrm{~m}$. Colonies (4 to $8 \mathrm{~cm}$ diameter) were removed from the base without damaging the tissue. The corals were collected at sea temperatures of $24 \pm$ $2^{\circ} \mathrm{C}$ and maintained in $2 \mathrm{l}$ aquaria at $24^{\circ} \mathrm{C}$ in artificial seawater (ASW) (Instant Ocean) adjusted to a salinity of $40 \mathrm{ppt}$. Water was replaced after 4 to $6 \mathrm{~d}$. The aquaria were aerated and illuminated with fluorescent lamps (Sylvania, Aquastar $10000 \mathrm{~K}$ ) at $12 \mathrm{~h}$ light:12 h dark intervals. Diseased corals showing signs of the white plague-like disease were collected in the same manner, except that generally larger colonies (5 to $20 \mathrm{~cm}$ diameter) were collected.

Isolation and enumeration of bacteria from healthy and diseased corals. Bacteria were removed from the corals by 2 methods: (1) crushing the corals in $10 \mathrm{ml}$ of sterile ASW with the aid of a mortar and pestle as previously described (Ben-Haim \& Rosenberg 2002) and (2) collecting mucus from the corals in the sea using a 25-ml syringe. In both cases, samples were diluted in ASW, and $0.1 \mathrm{ml}$ was spread onto MB (marine broth) agar plates $(1.8 \%$ Difco, MA 2216, $0.9 \% \mathrm{NaCl}$ and $1.8 \%$ Difco Bacto agar) and on Vibrio-selective TCBS (thiosulfate citrate bile salts sucrose) agar (4.5\% Difco TCBS agar, $0.9 \% \mathrm{MB}, 0.45 \% \mathrm{NaCl}$ and $1.2 \%$ Difco Bacto agar). Plates were incubated at $25^{\circ} \mathrm{C}$ for $3 \mathrm{~d}$. Estimation of culturable bacterial concentration was done by plating triplicate samples of appropriate dilutions. Pure cultures of bacteria from diseased corals were obtained by picking well-isolated colonies and restreaking them on MB agar. The pure cultures were stored in $15 \%$ glycerol at $-70^{\circ} \mathrm{C}$.

Phenotypic characterization of Strain BA-3. Strain BA-3 was routinely cultivated on MB liquid or agar media. Liquid cultures were prepared in $125 \mathrm{ml}$ flasks containing $10 \mathrm{ml} \mathrm{MB}$, inoculated with 1 colony and incubated at $30^{\circ} \mathrm{C}$, while shaking (160 rpm), for $48 \mathrm{~h}$. Cell morphology and motility were determined by phase microscopy. Biochemical classification tests were carried out by using an identification kit for Gram-negative bacteria: Api-20 NE (Bio Merieux SA, Marcy-Ietoil). The standard Api-20 NE method was used, except that the media were adjusted to $3 \%$ $\mathrm{NaCl}$. Sensitivity to antibiotics was examined using the paper disc method with $10 \mu \mathrm{g}$ antibiotic $\operatorname{disc}^{-1}$. Salt tolerance was determined with Peptone (Difco) containing different concentrations of $\mathrm{NaCl}$. For scanning electron microscopy (JEOL 840A), exponentially growing cells in $\mathrm{MB}$ medium were harvested by centrifugation; the pellets were washed in filtered $(0.2 \mu \mathrm{m}) \mathrm{ASW}$ and then negatively stained with $1 \%$ uranyl acetate.

DNA isolation, amplification and sequence analysis. Genomic DNA was isolated from a $2 \mathrm{ml}$ overnight bacterial culture, using the Wizard genomic DNA purification kit (Promega). 16S rDNA was amplified through the polymerase chain reaction (PCR) in a $50 \mu$ reaction mixture consisting of $5 \mu \mathrm{l}$ of $10 \times$ PCR buffer, $5 \mu \mathrm{l}$ of $2.5 \mathrm{mM}$ total dNTPs mixture, $1 \mathrm{mM}$ of each primer, $1 \mu \mathrm{g}$ template DNA and $2.5 \mathrm{U}$ of ex Taq DNA polymerase (Takara Shuzo). The primers used were general prokaryotic 16S rDNA primers: forward 5'AGAGTTTGATYMTGGCTCAG and reverse 5'ACCTTGTTACGACTT ( $\mathrm{Y}=\mathrm{C} / \mathrm{T}, \mathrm{M}=\mathrm{A} / \mathrm{C})$, manufactured by GenSet. Amplification conditions for the PCR included denaturation at $94^{\circ} \mathrm{C}$ for $5 \mathrm{~min}$, followed by 30 cycles of $94^{\circ} \mathrm{C}$ for $1 \mathrm{~min}, 55^{\circ} \mathrm{C}$ for $1 \mathrm{~min}$ and $72^{\circ} \mathrm{C}$ for $45 \mathrm{~s}$. The final extension step was at $72^{\circ} \mathrm{C}$ for $5 \mathrm{~min}$. Reaction products were purified and sequenced using the chain termination method in the ABI PRISM (Model 377, Version 3.3) automatic sequencer. Finally, the BA-3 16S rDNA sequence was compared with homologous published sequences in the NCBI sequence data base. 
Filtration/infection experiments. To determine the size of the infectious agent, aquarium water containing diseased Favia favus was collected $24 \mathrm{~h}$ after the corals had been placed in aquaria (referred to as 'diseased water' or DW). Then, 21 of DW were filtered through a $3 \mathrm{~mm}$ pore size filter, and an additional $2 \mathrm{l}$ were filtered through a $0.2 \mu \mathrm{m}$ pore size filter (both were Millipore filters). This procedure was repeated several times to yield 41 of $3 \mu \mathrm{m}$ filtrate, 281 of $0.2 \mu \mathrm{m}$ filtrate and 12 filters containing the $0.2 \mu \mathrm{m}$ retentate. Five sets of experiments were performed. Each set consisted of 2 to 10 separate 21 aquaria, each containing 2 healthy corals. The sets were: DW alone, the $3 \mu \mathrm{m}$ filtrate, the $0.2 \mu \mathrm{m}$ filtrate, the $0.2 \mu \mathrm{m}$ retentate plus sterile SW and the $0.2 \mu \mathrm{m}$ filtrate plus the $0.2 \mu \mathrm{m}$ retentate. The retentates (filters) were placed at the bottom of the aquaria without direct contact with the corals.

\section{RESULTS}

\section{Field observations}

The white plague-like disease was first observed on the Eilat coral reef in November 2002. Since January 2003, the disease has been studied systematically at depths of 2 to $4.5 \mathrm{~m}$ in 3 areas using 6 belt transects. This study continues, and the results will be published later. However, there are some basic observations that are relevant to this paper. The disease occurs most frequently on 2 of the major reef-building coral genera, Favia and Goniastrea. Approximately $10 \%$ of the colonies of each of these genera show progressive signs of the disease or are dead as a result of the dis- ease. The first sign of the disease is a small white spot, devoid of tissue, that appears at a random location on the coral. The white area then spreads (Fig. 1), with a maximum recorded rate of $11 \mathrm{~mm} \mathrm{~d}^{-1}$. In some cases, the spreading stops. Corals $<10 \mathrm{~cm}$ in diameter usually die, and the skeleton becomes covered with algae. The disease appears to be clustered, since the frequency of disease in corals that are adjacent (within $10 \mathrm{~cm}$ ) to a diseased coral is approximately $25 \%$, compared to $10 \%$ for random colonies.

\section{The white plague-like disease is infectious}

Coral colonies of Favia favus showing progressive signs of the white plague-like disease in the sea successfully infected healthy F. favus in controlled aquarium experiments (Table 1, Expt 1). The corals were not in direct contact, so the infectious agent must have been transmitted through the aquarium water. Furthermore, healthy corals that were infected in aquaria were able to infect a second group of healthy corals (Table 1, Expt 2). Infection was not species- or genusspecific, since diseased Favia sp. infected 3 other coral genera, Platygyra, Goniastrea and Favia (Table 1, Expts 3 to 5). In all cases examined, controls of healthy corals in the same aquarium did not show any signs of the disease for at least 1 mo. A photograph of a typical coral-to-coral infection experiment is shown in Fig. 2. Within the size range of corals used (4 to $20 \mathrm{~cm}$ diameter) there was no effect of size on infectivity.

To locate the site on a diseased coral that contained the infectious agent, a diseased coral was dissected into healthy, dead and spreading zones, and each frag-
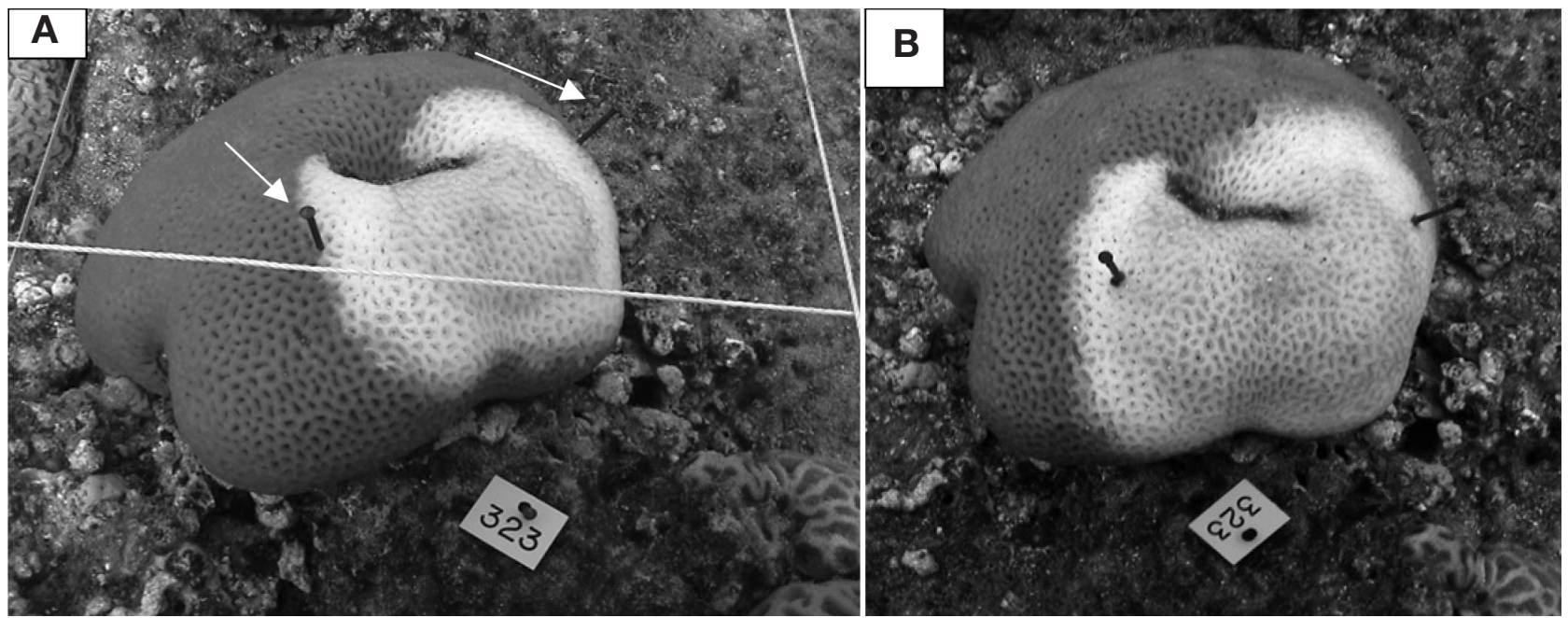

Fig. 1. Goniastrea sp. White plague-like disease on the Eilat coral reef. The white area on the colony surface is the bare skeleton remaining after tissue lysis. (A) Nails were inserted at the boundary between healthy and dead zones (arrows). (B) The spreading nature of the disease can be seen from the positions of the nails after $4 \mathrm{~d}$. The long axis of the tag (323) was $2 \mathrm{~cm}$ 
Table 1. Favia favus. Infection of healthy $(\mathrm{H})$ with diseased (D) corals; the 3 coral colonies in each aquarium were not in direct contact (n: the number of separate aquaria for each experiment)

\begin{tabular}{|c|c|c|c|}
\hline & $\mathrm{n}$ & Corals in aquarium & $\begin{array}{l}\text { S that died or } \\
\text { me diseased } \\
\text { after } 5 \mathrm{~d}\end{array}$ \\
\hline \multicolumn{4}{|c|}{ Expt } \\
\hline 1 & 5 & $1 \mathrm{D}^{\mathrm{a}}+2 \mathrm{H} F \cdot$ favus & $10 / 10$ \\
\hline 2 & 3 & $1 \mathrm{D}^{\mathrm{b}}+2 \mathrm{H}$ F. favus & $6 / 6$ \\
\hline 3 & 2 & $1 \mathrm{D}^{\mathrm{a}}$ F. favus + $2 \mathrm{H}$ Platygyra sp. & $4 / 4$ \\
\hline 4 & 2 & $1 \mathrm{D}^{\mathrm{a}}$ F. favus $+2 \mathrm{H}$ Goniastrea sp. & . $4 / 4$ \\
\hline 5 & 2 & $1 \mathrm{D}^{\mathrm{a}} F$. favus $+2 \mathrm{H} \mathrm{F.} \mathrm{favus}$ & $4 / 4$ \\
\hline \multicolumn{4}{|c|}{ Control } \\
\hline 1 & 10 & $3 \mathrm{H} \mathrm{F.} \mathrm{favus}$ & $0 / 30$ \\
\hline 2 & 10 & 3 H Platygyra sp. & $0 / 30$ \\
\hline 3 & 10 & 3 H Goniastrea sp. & $0 / 30$ \\
\hline 4 & 10 & 3 H F. favus & $0 / 30$ \\
\hline \multicolumn{4}{|c|}{$\begin{array}{l}\text { a The diseased F. favus was taken from the sea } \\
{ }^{\mathrm{b}} \text { The diseased F. favus was taken from a healthy coral that } \\
\text { became infected in Expt } 1\end{array}$} \\
\hline
\end{tabular}

ment was placed in a separate aquarium with 2 healthy Favia favus. After $3 \mathrm{~d}$, the corals in the aquarium with the fragment containing the spreading zone were infected. The fragments containing the dead and healthy zones did not cause infections for at least 1 mo. Thus, the infectious agent was concentrated at the spreading zone (the boundary between healthy and dead tissue).

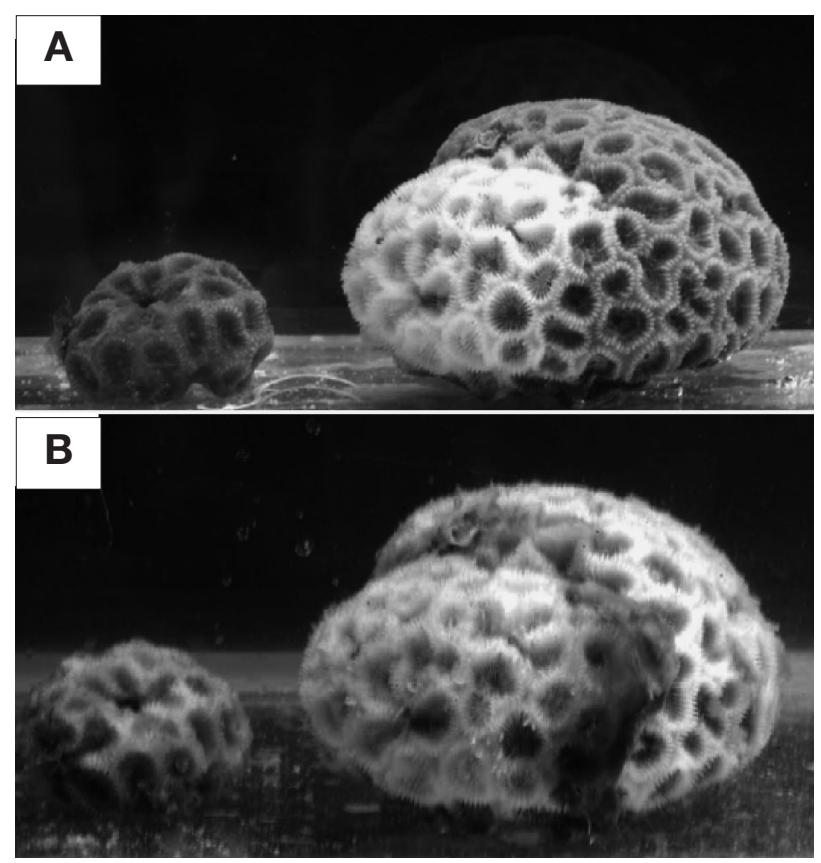

Fig. 2. Favia favus. (A) Infection of healthy coral (smaller specimen) held together with a diseased coral. (B) After $3 \mathrm{~d}$, the healthy coral has become diseased

\section{Enumeration of bacteria associated with healthy and diseased Favia favus}

The number of viable bacteria that could be recovered from healthy and diseased Favia sp. was determined by 2 methods: (1) crushing the coral and (2) removing the mucus with a syringe, as described in 'Materials and methods'. In each case, the recovered bacteria were diluted and plated on MB and TCBS agar (Fig. 3). Approximately the same size healthy and diseased corals were used in these experiments. Using the crushing method, diseased corals yielded ca. 80 and 100 times more bacteria than the healthy corals on MB and TCBS (Vibrio-specific) agar, respectively. Using the syringe method, diseased corals yielded 10000 times more bacteria than healthy corals on both media.

\section{Isolation of a bacterium from a diseased coral that causes rapid lysis of Favia favus in aquaria}

A total of 25 bacterial colonies were isolated from the spreading zone of diseased Favia favus. Each of them was grown as a pure culture on MB medium and then used to inoculate (final concentration: ca. $10^{6} \mathrm{ml}^{-1}$ ) aquaria containing healthy $F$. favus. No signs of the disease were observed in any of the aquaria for at least $1 \mathrm{mo}$. Since it is possible that more than 1 bacterial species is required for a successful infection, as has been reported for the black band disease of corals (Richardson 2004), an experiment was performed in which all 25 isolates were inoculated (ca. $10^{6} \mathrm{ml}^{-1}$ of each) into an aquarium containing healthy F. favus. Again, no signs of the disease were observed for 1 mo.

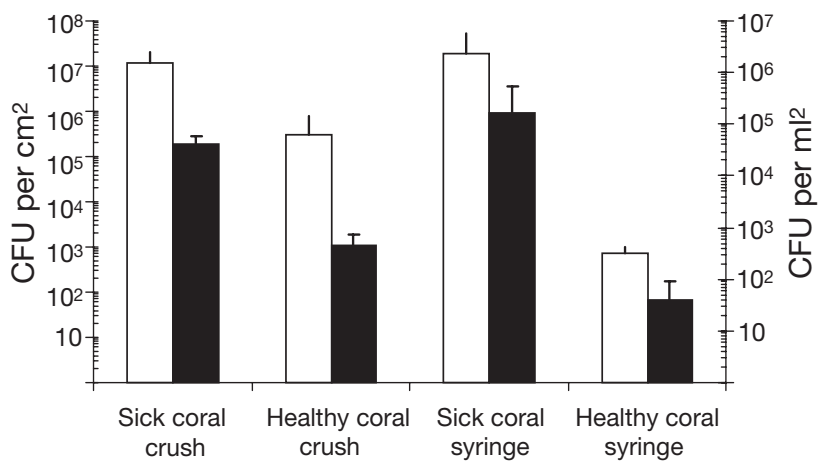

Fig. 3. Culturable bacteria associated with white plague-like diseased and healthy Favia favus. Bacteria were obtained either by crushing the corals in artificial seawater (colony-forming units [CFU] $\mathrm{cm}^{-2}$ ) or by collecting the mucus underwater (CFU $\mathrm{ml}^{-1}$ ), as described in 'Materials and methods'. After dilution, samples were plated on MB (open bars) and TCBS (closed bars) agar. Data are presented as means + SD $(n=6)$ 
Table 2. Favia favus. Filtration/infection experiments. The water (DW) surrounding a diseased $F$. favus in an aquarium was collected and filtered as described in 'Materials and methods' (n: the number of separate aquaria for each experiment, each aquarium had 2 corals)

\begin{tabular}{|lrll|}
\hline Expt & $\mathrm{n}$ & Fraction tested & Result \\
\hline 1 & 10 & DW & All infected in 3-6 d \\
2 & 2 & 3- $\mu$ m filtrate of DW & All infected in 3-4 d \\
3 & 10 & $0.2-\mu$ m filtrate of DW & None infected for 14 d \\
4 & 8 & Filter from Expt 3 & None infected for 14 d \\
5 & 4 & $0.2-\mu \mathrm{m}$ filter + filtrate & All infected in 4-7 d \\
\hline
\end{tabular}

The failure to infect corals with bacterial isolates led us to consider the possibility that the infectious agent was a virus or a eukaryotic microorganism. To test this possibility a series of filtration/infection experiments was performed, as summarized in Table 2. As predicted from the observation that diseased corals infected healthy ones in the same aquarium in the absence of direct contact, the water surrounding a diseased coral, referred to as diseased water (DW), caused rapid lysis of healthy corals (Table 2, Expt 1). The agent responsible for this lysis passed through $3 \mu \mathrm{m}$ pore size filters, but was retained by $0.2 \mu \mathrm{m}$ filters. Thus, the agent does not appear to be larger than $3 \mu \mathrm{m}$. Surprisingly, filters containing the particles larger than $0.2 \mu \mathrm{m}$ (retentate) did not cause lysis. However, the $0.2 \mu \mathrm{m}$ retentate plus the $0.2 \mu \mathrm{m}$ filtrate of DW always resulted in lysis ( $\mathrm{n}=8$ colonies). These data led to the hypothesis that the lysis agent was a bacterium

Table 3. Favia favus. Phenotypic characteristics of Strain BA-3

\begin{tabular}{ll}
\hline Observation & \\
\hline Growth on MB agar & $\begin{array}{c}\text { Mucoid, cream colored, } \\
\text { Mmm diameter }\end{array}$ \\
$\begin{array}{l}\text { Growth on TCBS agar } \\
\text { Cell morphology }\end{array}$ & $\begin{array}{l}\text { Rod } 1.5 \times 0.8 \mu \mathrm{m} \\
\text { Motility }\end{array}$ \\
$\begin{array}{l}\text { Growth at } 37^{\circ} \mathrm{C} \\
\text { Growth on } 2 \text { to } 4 \% \mathrm{NaCl}\end{array}$ & Negative \\
Antibiotic sensitivity & Positive \\
Biochemical tests & Positive \\
Indole production & \\
Nitrite from nitrate & Negative \\
Acidification of glucose medium & Weak positive \\
Arginine dihydrolase & Negative \\
Oxidase & Negative \\
Esculin hydrolysis & Negative \\
Gelatinase & Positive \\
$\beta$-galactosidase & Negative \\
Urease & Positive \\
aSensitive to erythromycin, kanamycin, gentamicin, \\
ampicillin, tetracycline
\end{tabular}

retained by the $0.2 \mu \mathrm{m}$ filter, but that an additional factor, present in the DW filtrate, was also required for successful infection.

Once it was discovered that a filterable factor was necessary for infection, each of the 25 bacteria originally isolated from the spreading zone of an active infection was re-tested for infectivity, but this time with the filtered DW. Only 1 of the pure cultures, referred to as BA-3, caused infection. In 4 aquarium experiments-each with 2 healthy Favia favus, Strain BA-3 $\left(10^{6} \mathrm{ml}^{-1}\right)$ plus filtered DW-lysis always occurred in 3 to $4 \mathrm{~d}$ ( $\mathrm{n}=8$ colonies). Thus, Strain BA-3 caused lysis of F. favus, but it required a filterable factor for successful infection. Strain BA-3 was isolated from the tissues of the laboratory-infected corals at the end of the experiment. Using $10^{5} \mathrm{BA}-3 \mathrm{ml}^{-1}$ in filtered DW led to infection in 6 to $8 \mathrm{~d}$, rather than 3 to $4 \mathrm{~d}$ as with $10^{6} \mathrm{BA}-3 \mathrm{ml}^{-1}$.

\section{Characteristics of Strain BA-3}

The phenotypic characteristics of Strain BA-3 are summarized in Table 3. It is a Gram-negative, motile, rod-shaped bacterium with a single polar flagellum (Fig. 4). Many of the cells appear to divide asymmetrically. Cultures of BA-3 emit a strong odor, resembling beetroot. The 16S rDNA sequence of Strain BA-3 (1356 bp in length; EMBL Accession No. AY643537) showed closest similarity to Eubostrichus dianae epibacterium $(94 \%)$.

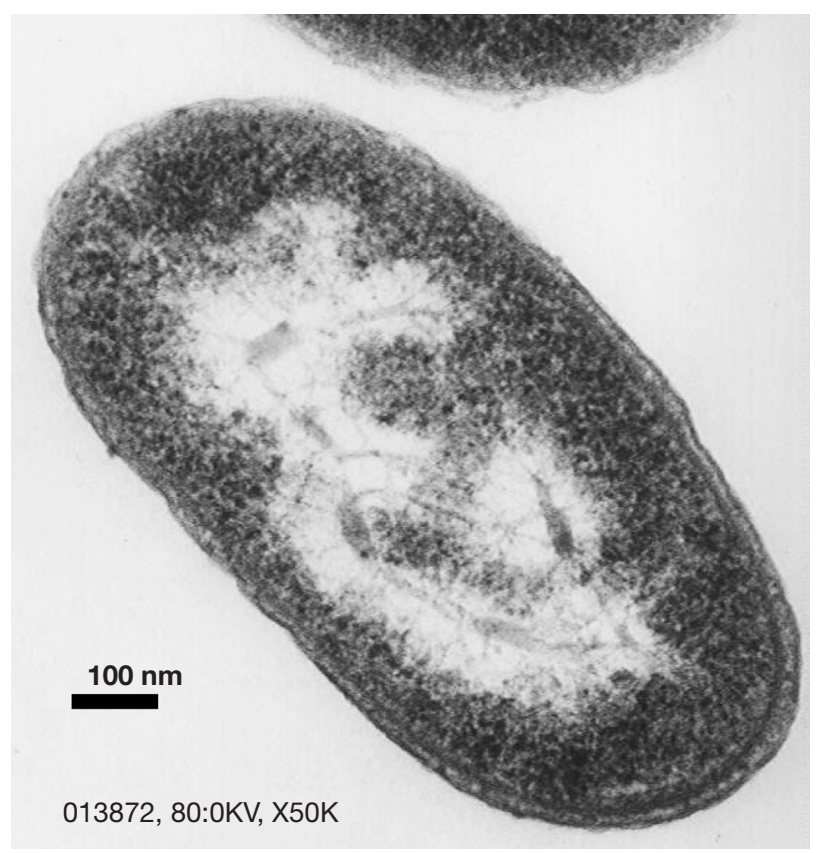

Fig. 4. Transmission electron micrograph of Strain BA-3 


\section{DISCUSSION}

The spreading nature of the white plague-like disease on the Eilat coral reef suggested that it is an infectious disease. This was confirmed in aquarium experiments by demonstrating that diseased corals transmit the disease to healthy ones. The disease was transmitted without direct contact between healthy and diseased corals, indicating that the infectious agent was present in the water. Diseased Favia favus infected 3 other coral genera, i.e. the infectious agent was not genus-specific. Dissection experiments showed that the pathogen was located specifically at the spreading zone, the border between healthy and dead zones.

Although the much higher number of viable bacteria associated with diseased corals than healthy ones provides another sign of the disease, these data do not distinguish between the higher numbers being the cause of the disease or the result of the disease. None of the colonies derived from diseased corals resembled the bacterium responsible for White Plague II, Aurantimonas coralicida, which yields golden pigmentation on MB agar (Denner et al. 2003). Initial attempts to infect healthy corals with pure bacterial cultures or mixtures of pure cultures obtained from the spreading zone failed. Several possible explanations were considered: (1) The infectious agent is a virus. So far, no viral diseases of corals have been reported, although viruses that multiply on symbiotic dinoflagellates have been described (Wilson et al. 2001). (2) The infectious agent is a eukaryotic microorganism that does not form colonies on the agar media employed in this study. (3) The infectious agent is a bacterium in the viablebut-not-culturable (VBNC) state. Entry of bacteria into the VBNC state has been reported repeatedly with a large number of marine species (Colwell et al. 1985, Oliver et al. 1991, Lee \& Ruby 1995). It has been demonstrated that the coral pathogen Vibrio shiloi is infectious while in the VBNC state (Israely et al. 2001). (4) The infectious agent is a bacterium that requires the presence of an extracellular virulence factor for infection. To distinguish between these 4 possibilities and to learn more about the infectious agent, a series of filtration/infection experiments was performed. The pathogen has a diameter of $<3 \mu \mathrm{m}$ and $>0.2 \mu \mathrm{m}$. This puts it in the size range of bacteria. The unexpected result was that the $0.2 \mu \mathrm{m}$ filter, which retained the pathogen, did not cause the disease when placed into the aquarium with healthy corals. However, when the $0.2 \mu \mathrm{m}$ filtrate was combined with the filter, the infection occurred. Thus, it was likely that the pathogen was a bacterium retained on the filter, but that a successful infection required some unknown component in the filtrate.
Once it was realized that a filterable component in 'diseased water' was necessary, but not sufficient, to cause the disease, we were able to demonstrate that only 1 of the 25 bacterial strains previously isolated from the spreading zone of a diseased coral caused lysis of Favia favus in aquaria. Based on its 16S rDNA sequence, Strain BA-3 is a new species. A detailed genotypic and phenotypic study of Strain BA-3 is now being carried out in order to classify it properly and determine whether it is not only a new marine species, but also a new genus.

The nature of the filterable factor required for infection is unknown. In principle, it could act by causing the coral host to be more susceptible to infection by the pathogen or making the pathogen more virulent. Until the filterable factor is purified and characterized, it would be premature to speculate on its mode of action. Preliminary experiments indicate that the filterable factor is inactivated by heat $\left(60^{\circ} \mathrm{C}, 1 \mathrm{~h}\right)$ and does not pass through a filter with a 5000 molecular weight (MW) cutoff.

It should be pointed out that the first of Koch's postulates was not satisfied in this study. We were unable to show that Strain BA-3 was present on all diseased corals. Several attempts to re-isolate Strain BA-3 from diseased corals in the field were unsuccessful. It is possible that BA-3 is present in a culturable form in low numbers. Until a selective medium is developed for Strain BA-3, or, alternatively, a species-specific molecular probe is constructed and used to test for the presence or absence of the bacterium in healthy and diseased corals, we cannot conclude that BA-3 is the causative agent of the white plague-like disease on the Eilat coral reef.

Acknowledgements. This work was supported by the Pasha Gol Chair for Applied Microbiology and the Israel Center for Emerging Diseases to E.R., the Raynor Chair for Environmental Conservation Research to Y.L. and The Israel Science Foundation Grant 1033/03.

\section{LITERATURE CITED}

Antonius A, Reigl B (1997) A possible link between coral diseases and corallivorus (Drupella cornus) snail outbreak in the Red Sea. Atoll Res Bull 47:1-9

Ben-Haim Y, Rosenberg E (2002) A novel Vibrio sp. pathogen of the coral Pocillopora damicornis. Mar Biol 141:47-55

Ben-Haim Y, Zicherman-Keren M, Rosenberg E (2003a) Temperature-regulated bleaching and lysis of the coral Pocillopora damicornis by the novel pathogen Vibrio coralliilyticus. Appl Environ Microbiol 69:4236-4242

Ben-Haim Y, Thompson FL, Thompson CC, Cnockaert MC, Hoste B, Swings J, Rosenberg E (2003b) Vibrio coralliilyticus sp. nov., a temperature-dependent pathogen of the coral Pocillopora damicornis. Int J Syst Evol Microbiol 53: 309-315

Bythell J, Pantos O, Richardson L (2004) White plague, white 
band, and other 'white' diseases. In: Rosenberg E, Loya Y (eds) Coral health and disease. Springer-Verlag, Berlin, p 351-364

Colwell RR, Brayton PR, Grimes DJ, Roszak DB, Huq SA, Palmer LM (1985) Viable but non-culturable Vibrio cholerae and related pathogens in the environment: implications for release of genetically engineered microorganisms. Bio Technol 3:817-820

Denner EB, Smith GW, Busse HJ, Schumann P, Narzt T, Polson SW, Lubitz W, Richardson LL (2003) Aurantimonas coralicida gen. nov. sp. nov., the causative agent of white plague II on Caribbean scleractinian corals. Int J Syst Evol Microbiol 53:1115-1122

Dustan P (1977) Vitality of reef coral populations off Key Largo, Florida: recruitment and mortality. Environ Geol 2: 51-58

Geiser DM, Taylor JW, Ritchie KB, Smith GW (1998) Cause of sea fan death in the West Indies. Nature 394:137-138

Green EP, Bruckner AW (2000) The significance of coral disease epizootiology for coral reef conservation. Biol Conserv 96:347-361

Israely T, Banin E, Rosenberg E (2001) Growth, differentiation and death of Vibrio shiloi in coral tissue as a function of seawater temperature. Aquat Microb Ecol 24:1-8

Kushmaro A, Loya Y, Fine M, Rosenberg E (1996) Bacterial infection and coral bleaching. Nature 380:396

Kushmaro A, Rosenberg E, Fine M, Loya Y (1997) Bleaching of the coral Oculina patagonica by Vibrio AK-1. Mar Ecol Prog Ser 147:159-165

Lee KH, Ruby EG (1995) Symbiotic role of the viable but nonculturable state of Vibrio fischeri in Hawaiian coastal

Editorial responsibility: Jed Fuhrman,

Los Angeles, California, USA seawater. Appl Environ Microbiol 61:278-283

Loya Y (2004) The coral reefs of Eilat-past, present and future: three decades of coral community structure studies. In: Rosenberg E, Loya Y (eds) Coral health and disease. Springer-Verlag, Berlin, p 1-29

Loya Y, Sakai K, Yamazato K, Nakano Y, Sembali H, van Woesik R (2001) Coral bleaching: the winners and losers. Ecol Lett 4:122-131

Oliver JD, Nilsson L, Kjelleberg S (1991) Formation of nonculturable Vibrio vulnificus cells and its relationship to the starvation state. Appl Environ Microbiol 57:2640-2644

Patterson KL, Porter JW, Ritchie KB, Polson SW, Mueller E, Peters EC, Santavy DL, Smith GW (2002) The etiology of white pox, a lethal disease of the Caribbean elkhorn coral, Acropora palmata. Proc Natl Acad Sci USA 99:8725-8730

Richardson LL (1998) Coral diseases: What is really known? Trends Ecol Conserv 13:438-443

Richardson LL (2004) Black band disease. In: Rosenberg E, Loya Y (eds) Coral health and disease. Springer-Verlag, Berlin, p 325-335

Richardson L, Goldberg W, Kuta K, Aronson R and 5 others (1998) Florida's mystery coral killer explained. Nature 392: $557-558$

Rosenberg E, Loya Y (2004) Coral health and disease. Springer-Verlag, Berlin

Weil E (2004) Coral reef diseases in the wider Caribbean. In: Rosenberg E, Loya Y (eds) Coral health and disease. Springer-Verlag, Berlin, p 35-64

Wilson WH, Francis I, Ryan K, Davy SK (2001) Temperature induction of viruses in symbiotic dinoflagellates. Aquat Microb Ecol 25:99-102

Submitted: July 29, 2004; Accepted: January 20, 2005

Proofs received from author(s): August 4, 2005 